\title{
Феномен протестной активности личности: субъектно-бытийная интерпретация
}

\author{
Александр Ш. Гусейнов ${ }^{*}$, Зинаида И. Рябикина², Галина Ю. Фоменко², \\ Виктория В. Шиповская ${ }^{2}$ \\ ${ }^{1}$ Кубанский государственный университет физической культуры, спорта и туризма, \\ г. Краснодар, Российская Федерация \\ ${ }^{2}$ Кубанский государственный университет, г. Краснодар, Российская Федерация \\ *E-mail: AGuseinov@yandex.ru
}

\begin{abstract}
Аннотация
Ввеление. Рассматриваются положения субъектно-бытийного подхода и Аемонстрируются его возможности Аля описания феноменологии протестной активности Аичности. ПреАставлен обзор теоретико-методологических Молелей, созАанных в рамках Аанного поАхода. Субъектно-бытийный поАхоА ориентирован на выявление и анализ ценностных оснований мичностной бытийности, а также возникающих и разрешаемых ^ичностью противоречий в пространствах ее бытия. Исходя из понимания протестной активности как процесса, направленного на Аеконструкцию микро- и макросоциума сообразно особенностям личностного самоопределения, в качестве к^ючевых показателей системы протестной активности рассматриваются ценностно-смысловое позиционирование и экзистенциальное самоопределение. Представлены структурно-диалектическая молель протеста, типология протестных фрорм и осуществлен их анализ, как модусов бытия, фрормирующихся в результате субъектной активности ^ичности.
\end{abstract}

Метолы. В эмпиричеСКОМ исСАеАОвании ценностно-СмысАового позиционирования ^ичности в Аеструктивных фрормах протеста ( $\mathrm{n}=2600 ; \mathrm{M}=21,3$ гола) использован опросник «Протестная активность мичности», состоящий из шкал: эмансипация, негативизм, оппозиция, эскапизм, ниги^изм. Тест валилен, согласован (а-Кронбаха от 0,63 $А$ 0 0,81) и структурирован, пятифракторная молель конфирматорного анамиза: CMIN/DF = 1,084; IFI = 0,987; CFI = 0,989; RMSEA = 0,013. Применялись фракторный и корреляционный анализ.

Результаты. Аоказано, что желание выразить масштаб собственной личности на фоне выбора социально не одобряемых вариантов субъектного позиционирования составляет суть ценностно-смыслового противоречия в неконструктивных фоормах протеста (оппозиция, нигилизм, эскапизм, негативизм). Аица с неконструктивными типами протеста не принимают неопределенность внешнего и внутреннего мира и отказываются от экзистенциального самоопределения. В Аеструктивных фрормах протеста происходят дефрормация и Аевальвация духовных ценностей. 
ОбсужАение результатов. У лиц с неконструктивными типами протеста ^ичностные противоречия связаны с проблемой отчужления и самоилентификации, с неспособностью формировать и подлерживать аутентичное бытие. Накапливаясь, эти противоречия приобретают непреололимый характер, обусловливая ск^онность к Аеструктивному протесту. Подчеркивается важность устранения причин Аеструктивной активности ^ичности: созАание условий А^я успешной поАростковой и взрослой социализации.

\section{КАючевые слова}

протестная активность Аичности, субъектно-бытийный поАХОА, эКзистенциальное самоопределение, ценностно-смысловые противоречия, структурно-Аиалектическая модель, модус бытия, оппозиция, нигилизм, эскапизм, негативизм

\section{Основные положения}

- протестная активность рассматривается как мичностная характеристика и анализируется как разновиАность моАусов бытия;

- протестная активность Аичности проявляет уровень экзистенциального развития человека, особенности субъектной позиции;

- желание распространять собственный масштаб, расширять возможности влияния на микро- и макросоциум и объектные типы позиционирования ^ичности составляют суть ценностно-смысловых противоречий в Аеструктивных формах протеста.

\section{Для цитирования}

Гусейнов А. Ш., Рябикина 3. И., Фоменко Г. Ю., Шиповская В. В. Феномен протестной активности личности: субъектно-бытийная интерпретация // Российский психологический журнал. - 2017. - Т. 14, № 4. - С. 78-96.

Материалы статьи получены 07.06.2017 


\title{
The Phenomenon of Protest Activity: A Subjective- Existential Interpretation
}

\author{
Aleksandr Sh. Guseinov ${ }^{1 *}$, Zinaida I. Ryabikina ${ }^{2}$, Galina Yu. Fomenko², \\ Viktoriya V. Shipovskaya ${ }^{2}$ \\ ${ }^{1}$ Kuban State University of Physical Education, Sport and Tourism, Krasnodar, Russian \\ Federation \\ ${ }^{2}$ Kuban State University, Krasnodar, Russian Federation \\ *Correspondence author. E-mail: AGuseinov@yandex.ru
}

\section{Abstract}

Introduction. The paper (a) presents the principles of the subjective-existential approach, (b) overviews its theoretical and methodological models, and (c) describes the phenomenology of protest activity. The subjective-existential approach focuses on value foundations of personal being, and also the way the individual resolves contradictions in the spaces of his/her life. Protest activity deconstructs micro- and macro-society in accordance with personal self-determination. Value-meaning positioning and existential self-determination are key characteristics of the protest activity system. The study introduces (a) a structural dialectical model of protest, and (b) typology of protest forms. These protest forms are modes of being, resulting from individual subject activity. Methods. The empirical study of value-meaning positioning in destructive protest forms ( $n=2600 ; M=21.3$ years) employed the Protest Activity Questionnaire which included the following scales: emancipation, negativism, opposition, escapism, and nihilism. The test was valid, reliable (Cronbach's alpha (a) ranged from 0.63 to 0.81), and structured. Confirmatory Factor Analysis Model was as follows: CMIN/DF = 1,084; $\mathrm{IFI}=0,987 ; \mathrm{CFI}=0,989 ; \mathrm{RMSEA}=0,013$. The study employed factor and correlation analysis. Results. A value-meaning contradiction in the destructive forms of protest (opposition, nihilism, escapism, and negativism) consisted in the respondents' desire to express their personality by choosing socially unapproved forms of subjective positioning. Individuals with non-constructive forms of protest did not accept the uncertainty of the external and inner world and refused existential self-determination. Deformation and devaluation of spiritual values were characteristic for destructive forms of protest. Discussion. Personal contradictions depend on the problem of alienation, selfidentification, and also inability to form and maintain an authentic being in individuals with non-constructive forms of protest. When accumulating, these contradictions become insuperable and cause destructive protest. Addressing the causes of the person's destructive activity - creating conditions for successful adolescent and adult socialization - is important. 


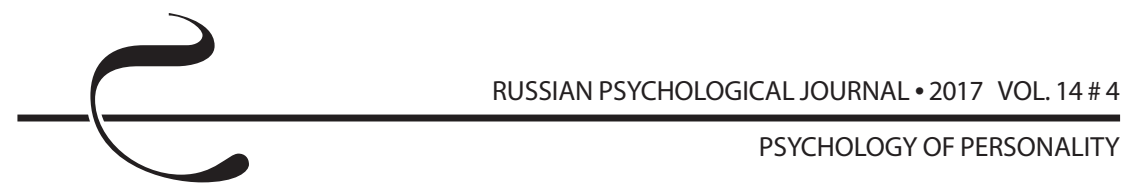

\section{Keywords}

protest activity, subjective-existential approach, existential self-determination, valuemeaning contradictions, structural dialectical model, mode of being, opposition, nihilism, escapism, negativism

\section{Highlights}

- Protest activity is a mode of being and personal characteristic.

- Protest activity displays the level of personal existential development and characteristics of subject stand.

- Value-meaning contradictions in the destructive forms of protest consist in object types of positioning, and also the person's desire to express his/her personality, extend his/her influence on micro- and macro-society.

\section{For citation}

Guseinov A. Sh., Ryabikina Z. I., Fomenko G. Yu., Shipovskaya V. V. The Phenomenon of Protest Activity: A Subjective-Existential Interpretation. Rossiiskii psikhologicheskii zhurnal Russian Psychological Journal, 2017, V. 14, no. 4, pp. 78-96 (in Russian).

Original manuscript received 07.06.2017

\section{Введение}

На современном этапе развития психологии актуализируются новые формы психологического познания, в основу которых органично включены процессы самотрансформации личности и различные способы самопорождения субъекта [1, 2, 3]. В связи с этим можно констатировать трансформацию пропорций интра- и интерактивного подходов в анализе и интерпретации психики [4, 5], опосредующих изменения в категориальном аппарате психологической науки. В фокусе внимания сложнейший синтетичный феномен - «бытие человека», представляющее собой организованную иерархию различных способов человеческого существования $[6,7,8]$. Психология человеческого бытия и рассмотрение личности как субъекта бытия, интегрирующего разнородные закономерности, приобретают особое значение, меняя точку зрения на сопутствующую психологии личности проблематику [9, 10, 11]. Заложенные в идеях С.Л. Рубинштейна [6] и А.В. Брушлинского [12] концептуальные посылы реализовались в развитии субъектно-бытийного подхода к изучению личности, который позволил преодолеть ограниченность адаптивной парадигмы, дающей узкое представление о многомерных и многоуровневых феноменах, а с другой стороны, дал возможность современного объяснения полидетерминированных и мультифакторных процессов, обуславливающих бытие, в которых личность является субъектом. 
В рамках данного направления личность и ее бытие предстают как взаимозависимые и взаимообусловливающие друг друга стороны неразрывного целого $[13,14,15]$.

Субъектно-бытийный подход, акцентирующий внимание на различиях в субъектности человека в различных пространствах, получил развитие и конкретизацию в структурно-динамической модели личности и ее бытийных пространств (3.И. Рябикина) [13, 16], в модели экстремального и предельного существования (Г.Ю. Фоменко) [7, 17], в концепции понимания личностью собственной этнокультурной идентичности (О.Р. Тучина) и в модели события личности в браке (А.Р. Тиводар) [16], в теоретико-феноменологической модели субъектной активности личности в переговорах (Г.Г. Танасов) [14], в структурно-диалектической модели протестной активности личности (А.Ш. Гусейнов) [9], а также в рамках психологии личностной беспомощности и преодолевающей активности (В.В. Шиповская) [8, 11]. Созданные и доказавшие свою эвристичность теоретико-феноменологические модели перечисленных авторов, где осуществлен поворот от исследования отдельных особенностей объектов к изучению многомерных связей между ними, открыли возможности для системного рассмотрения и психологического анализа процессуальной природы разнообразной феноменологии.

Выполненные в рамках данного подхода исследования и оцениваемые перспективы демонстрируют возросшую роль методологического принципа единства личности и ее бытия. Субъектно-бытийный подход ориентирован на конструктивистское понимание личности и ее бытия, на исследование последствий того, что пространства бытия личности все более виртуализируются, теряя при этом естественную пространственно-временную развертку и прихотливо «сворачиваясь-разворачиваясь» по законам ментального процесса, на анализ эффектов «хаотизации», нарастающих проблем с прогнозом в изменениях бытия, из-за возрастающего количества акторов с различающимися векторами субъектной активности.

В ряду самых актуальных тем, решаемых в контексте субъектно-бытийного подхода, находится проблема ценностных оснований личностной бытийности и тема возникающих и разрешаемых личностью противоречий в различных пространствах ее бытия [7, 16, 18]. Личность, будучи субъектом, преодолевает антиномию внешней реальности и внутреннего мира таким образом, что внешняя реальность реорганизуется по законам ее внутреннего мира; тем самым личность «транслирует» себя на внешние бытийные пространства посредством самореализации, персонализации, расширяя границы своего бытия [13]. Стремясь к созданию аутентичного бытия и сохранению личностной целостности, субъект реализует в своем поведении три взаимодополняющие основные потребности: в подтверждении собственной значимости для 
внешнего мира, во внутренней согласованности, в самоактуализации [14]. Неуспешность процесса самоопределения личности в противоречиях современности (макросоциальных координатах) рассматривается как общая основа социальных деструкций $[7,10,17]$. Соответственно, положения субъектно-бытийного подхода позволяют выявить противоречия, складывающиеся между суммой требований, предъявляемых к личности и особенностями ее самоопределения, переосмыслить психологическое содержание различных социальных деструкций, возможные способы и пути их преодоления. Из вышеперечисленных положений видно, что психологи данного направления обращаются к внутреннему миру субъекта, выявляя позицию личности по отношению к бытию.

\section{Протестная активность личности в субъектно-бытийной uнтерпретации}

В рамках этой статьи мы концентрируемся на проблематике протестной активности личности, тем самым демонстрируя возможности субъектно-бытийного подхода для описания той части психологической феноменологии современности, которая находится под большим влиянием социальных обстоятельств бытия личности и ее экзистенциального развития, и предполагает активную междисциплинарную включенность в со-интерпретацию феномена. Проблема протестной активности личности попадает в фокус внимания исследователей не только в связи с нарастающим глобализмом террористических акций, но также в связи с повышенной откликаемостью молодежи на воздействия вербовщиков самых различных объединений (новых религиозных движений, тоталитарных сект, экстремистских группировок и т. п.) [16, 17, 18, 19].

В психологии феномен протеста рассматривался в различных проблемных и теоретических аспектах:

- протест как проявление формирующегося жизненного стиля личности (А. Адлер);

- ненормативная протестная реакция как ответ на негативный тип привязанности (Д.В. Винникотт, Дж. Боулби, Р.А. Шпиц, Е.Т. Соколова);

- протест как один из ключевых атрибутов детских и подростковых возрастных кризисов (Л.С. Выготский, Д.Б. Эльконин, Л.И. Божович);

- протест как дезадаптивное поведение, свойственное преимущественно девиантным подросткам (А.Е. Личко, В.Д. Менделевич, С.В. Березин, С. А. Куликова);

- протест как одно из проявлений определенных типов личностных расстройств (Т. Миллон);

- протест как стремление к автономии (А.А. Реан, Н.Е. Харламенкова, Е. В. Кумыкова, А. К. Рубченко); 
- протест в контексте формирования идентичности (К. Хорни, Х. Кохут, Э. Эриксон, М. Сейджман);

- протест как следствие экзистенциального вакуума и отчуждения (Э. Фромм, С. Мадди, И. Ялом, М. Чиксентмихайи, А. Лэнгле);

- протест как процесс доминирования целевого или метацелевого состояния (М. Аптер, M.R. McDermott, N.B. Barik) [9, 18, 19, 20, 21 и др.].

Существенно прояснить предикторы актуализации протеста позволяют многочисленные социологические концепции, где объясняется склонность к нормативным и ненормативным способам протеста (Г.В. Баранова [22], S. L. Blader [23], T. R. Gurr [24], B. Klandnermans [25], J. Van Stekelenburg [26], M. Van Zomeren [27] и пр.). В контексте модели относительной депривации протестная активность появляется в результате сопоставления настоящего уровня жизни человека с его наилучшими достижениями в предыдущем периоде или сравнения его заработков с зарплатой наиболее эффективных и значимых для него лиц [28]. Протестная активность может быть вызвана социальным неравенством и статусной позицией, усиливающими дисбаланс между ожиданиями и возможностями их реализации $[24,29,30]$. В данном случае речь идет об особом типе социального действия, порождаемого наличием противоположных интересов, недовольством условиями жизни и перспективами их изменения [22], вызывающего раздражение и возмущение, что не исключает возможности изучения его психологических закономерностей применительно к личности как субъекту протестной активности, выражаемой в присущей личности индивидуальной форме. Следует подчеркнуть, что в условиях неопределенности и транзитивности современного мира возможности линейных традиционных моделей протестной активности заметно ограничены вследствие того, что они описывают одномерную модель активности, т. е. детерминированного человека [30, 31, 32]. Почти не затрагивается многозначность проявлений протеста, не учитывается ценностно-смысловой уровень личности, а также присущие конкретному социально-историческому контексту противоречия, в которых должна самоопределяться личность.

Этот же аспект подчеркивает T.R. Gurr. По его мнению, для того чтобы понять, каким образом в процессе коммуникации создается чувство идентичности и общности целей у людей разных национальностей и различного вероисповедания, позволяющее осуществлять их успешную мобилизацию на протест, нужно обратить внимание на общества, где живут протестующие, их религиозные предпочтения, тип культуры и на другие факторы [33]. Утверждение T.R. Gurr показывает трудность раскрытия усилителей индивидуальной протестной мотивации. Именно поэтому в исследовании феномена протестной активности нужно обращать внимание на психологические 
механизмы явления, раскрывающие то, что для человека значимо, каким образом происходит изменение мировоззрения, переоценка ценностей, обеспечивающих кардинальную смену социальной позиции.

Протестная активность рассматривается нами не в социально-политическом, а в онтологическом аспекте; анализируется динамика личностного самоопределения в макросоциуме, формирующего систему личностных ценностей и смыслов и определяющего разные варианты протестной активности. В определении протестной активности личности подчеркивается ее направленность на деконструкцию микро- и макросоциума в соответствии с личностным выбором, а также динамика и неоднозначность феномена [9].

Принимая за основу методологический принцип субъекта, позволяющий преодолеть дефицитарность и упрощенность инструментальной трактовки феномена как поведенческих проявлений, а также синтезировать данные многочисленных и разрозненных исследований в целостную систему представлений, нами были выделены и операционализированы деструктивные типы протестной активности личности (негативизм, оппозиция, нигилизм, эскапизм), представлены конструктивные типы активности (высший эскапизм, эмансипация).

Выделяя различные формы протеста в концепции протестной активности, мы опирались на положения С.Л. Рубинштейна о двух принципиально разных способах существования [6] и их уточнение в концепте бытия личности в экстремальных условиях с определением двух модусов бытия личности (предельного и экстремального) [7]. Анализ этих конструктов дал возможность построить структурно-диалектическую модель протестной активности личности и содержательно переосмыслить в контексте проблем протеста представленную выше структуру модусов бытия. Данная интегрирующая теоретическая структура включает: рассмотрение типа субъектности и характера экзистенциального самоопределения в сочетании с ценностно-смысловым позиционированием; анализ способов решения многоуровневых противоречий, особенностей построения образа мира, специфики аффективно-потребностной сферы; учет организации личной активности. Избранный исследовательский путь позволил рассматривать проблему протестной активности в широком онтологическом ракурсе, не замыкаясь в рамках девиантности и адаптивной парадигмы. Протестная личность представлена в качестве субъекта разрешения противоречий. Мы смогли обратить внимание не только на внешние социокультурные признаки изучаемого феномена, но и на его внутреннее экзистенциальное содержание. В основе дифференциации форм протестной активности по параметру конструктивности лежит способ личностного позиционирования - субъектный или объектный; формы протеста различаются также по 
масштабу и особенностям противоречий, по возможностям эффективного разрешения.

\section{Методы}

Масштабное исследование изучения специфики протестной активности личности было организовано нами в Краснодарском крае. Выборка была репрезентативной по основным параметрам. В исследовании приняли участие подростки, юноши и девушки, молодежь ( $M=21,3$ года). Мы применили мультишкально-полиметодический подход, предполагающий использование комплекса методов, позволяющих описать структуру ценностно-смысловой сферы личности, копинг-стратегии, картину мира, регуляторные умения, субъективное благополучие, защитные механизмы, способы самоактуализации личности, особенности аффективной и мотивационно-потребностной сфер и другие характеристики. Участникам исследования были предъявлены 24 методики, проанализировано 228 показателей. Объем выборочной совокупности варьировал от $\mathrm{n}=2600$ до $\mathrm{n}=300$. В исследовании применялся опросник «Протестная активность личности» (ПАЛ), состоящий из шкал-факторов: эмансипация, негативизм, оппозиция, эскапизм, нигилизм (выборка $\mathrm{n}=2600$ ). Тест надежен, обладает конструктной валидностью, согласован (а-Кронбаха от 0,63 до 0,81) и структурирован, пятифакторная модель конфирматорного факторного анализа показывает хорошее соответствие данным: CMIN = 696,698; $\mathrm{P}=0,070 ; \mathrm{CMIN} / \mathrm{DF}=1,084 ; \mathrm{NFI}=0,877$; $\mathrm{IFI}=0,987 ; \mathrm{CFI}=0,989 ; \mathrm{RMSEA}=0,013$. Применялись факторный, корреляционный, дисперсионный и регрессионный виды анализа.

В данной статье приводятся и обсуждаются только результаты по следующим параметрам протестной активности - особенностям экзистенциального выбора и ценностно-смыслового позиционирования у лиц, реализующих деструктивные протестные формы. Акцент на этих ключевых параметрах дает возможность детально описывать личностные противоречия в разнообразных бытийных пространствах, под знаком которых осуществляется протестная активность определенного рода. В рамках данной статьи рассмотрим корреляционные связи шкал методики «ПАЛ» со шкалами тестов, определяющих базовые ценности личности и вероятность их искажений («Тест смысложизненных ориентаций» (СЖО) в адаптации Д.А. Леонтьева, «Опросник терминальных ценностей» (ОТЕЦ) И.Г. Сенина, методика оценки ценностей С. Шварца, тест психологических защит Р. Келлермана - Г. Плутчика), а также возможности самоактуализации (САТ - адаптированный опросник Э. Шострома).

\section{Результаты}

В процессе проведенного исследования предполагалось доказать связь неконструктивных типов протестной активности личности с обесцениванием 


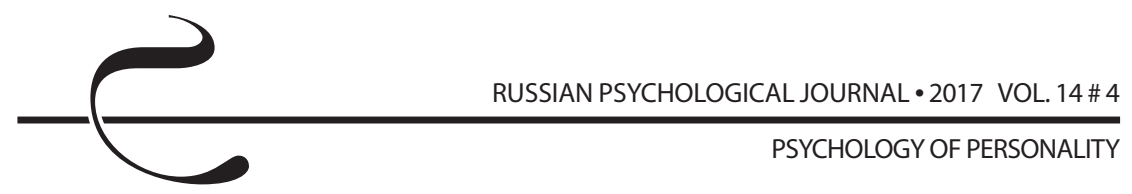

высших духовных ценностей. Этот тезис подтверждается полученными значимыми негативными корреляциями ( $<<0,05 ; \mathrm{p}<0,01)$ показателей опросника И.Г. Сенина со шкалой «эскапизм». У личности с эскапистскими установками нет выраженной потребности к обретению достойного статуса, власти и материально благополучной жизни; кроме того, нет стремления к самоактуализации и саморазвитию; высшие ценности и духовные потребности не актуализированы. Полученные значимые отрицательные связи эскапизма с показателями методики СЖО также свидетельствуют о слабой осмысленности жизни и ее этапов, о несформированности рефлексивных процессов. Получена значимая связь эскапизма со стремлением к стимуляции; наблюдается низкая оценка риска, игнорирование опасности.

Об атрибутивных особенностях нигилизма свидетельствуют отрицательные связи ( $<<0,01)$ с безопасностью, достижениями и личной властью, согласно опроснику С. Шварца. Показатели шкалы нигилизма имеют отрицательные связи ( $p<0,01)$ с показателями духовности, саморазвития и принятием человека, самоуважением (по САТ). Результаты негативных корреляций нигилизма со шкалами методики И.Г. Сенина $(p<0,05)$ достраивают общую панораму ценностей нигилиста как бездуховной личности.

Рассмотрим особенности негативизма. Отрицательные корреляции параметра «негативизм» со шкалами духовного роста, развития себя, стремления к достижениям, а также отрицательные корреляции со сферами учебы и получения профессии методики ОТеЦ говорят о примитивизме, «плоскости», бездуховности личности негативиста. Преобладают ценности стремления к новым ощущениям, переживаниям и власти. Все шкалы методики СЖО имеют значимые негативные корреляции со шкалой негативизма.

Близкая по содержанию система личностной деформации определена и у лиц с выраженными оппозиционными установками. Выявлены негативные корреляции ( $<0,01)$ показателя оппозиции со шкалами методики СЖО: «Цели», «Процесс» и «Результат», указывающие на слабую осмысленность жизни, невозможность простроить временную перспективу, управлять жизнью, желание жить «одним днем». Корреляции шкалы оппозиции с ценностями достижений, духовности незначимы. Экзистенциальный вакуум, непонимание смысла жизни, несформированность интереса к жизни, неспособность к осуществлению жизненных задач приводят к неудовлетворенности. Выявлены значимые отрицательные связи шкалы «Оппозиции» со шкалой «Самоуважение» самоактуализационного теста и «темпоральными» шкалами методики СЖО ( $p<0,05-\mathrm{p}<0,01)$. Ценности власти, безопасности, стимуляции по методике С. Шварца не дали значимых корреляций со шкалой «Оппозиции» $(p<0,1)$. 


\section{Обсуждение результатов}

Выявлены базовые противоречия эскапизма: между представлением о правильности собственного способа существования и его отрицательной оценкой со стороны общества; между индивидуальным восприятием бытия и реальностью. Из-за невозможности адекватно оценивать и преодолевать противоречия реальность воспринимается опасной, несправедливой, враждебной по контрасту с идеальной, иллюзорной жизнью, лучшей и справедливой, поэтому выбираются разнообразные формы ухода, избегания реальности, в частности, бегство в виртуальную реальность. Несформированность положительных ценностных ориентаций, размытая идентичность, неспособность управлять собой и собственной жизнью, конформизм и ведомость, избегание экзистенциальных проблем (экзистенциальное отступничество) делают личность с эскапистскими установками весьма уязвимой для манипуляции. Таким образом, наблюдаются основания для возникновения безвольной подчиненности любой идеологии.

Глубокая девальвация ценностей жизни и деградация духовных потребностей выражена и в нигилизме. Особенностью нигилизма является активное воспроизводство антигуманных ценностей, которое нередко связано с личной выгодой. Призывы к свободе, обосновываемые необходимостью сметания любых барьеров, запретов, условностей, устаревших норм, на самом деле выражают желание нигилиста принадлежать к группе «избранных» и поиск преференций для себя. Отстаивая «право силы» или призывая к моральному релятивизму, вседозволенности, нигилист заранее создает самооправдание для любых своих действий. Всепроникающая деструктивность, девальвация духовных ценностей, ненависть к жизни, экзистенциальное отступничество тесно связаны с дефензивными механизмами, среди которых преобладают вытеснение, замещение и интеллектуализация. Анализ ценностей нигилиста указывает на примитивность личности, отчужденность от мира и самого себя, неразвитость рефлексии и отсутствие возможности отслеживать противоречия и продуктивно их решать вследствие нравственной отсталости. Профиль нигилистической личности представлен глубоким провалом в сфере духовности наряду с искаженной целевой доминантой, когда смыслом существования нигилиста становится тотальность отрицания всего развивающегося, жизненного, позитивного. В силу тотальной деструктивности нигилиста и его неспособности разрешать противоречия формируется особый способ существования, свободный от норм, морали и традиционных ценностей. Базовое ценностно-смысловое противоречие нигилизма - несоответствие между бытием и долженствованием. Характер экзистенциального самоопределения при нигилизме связан с экзистенциальным отступничеством и обусловлен 


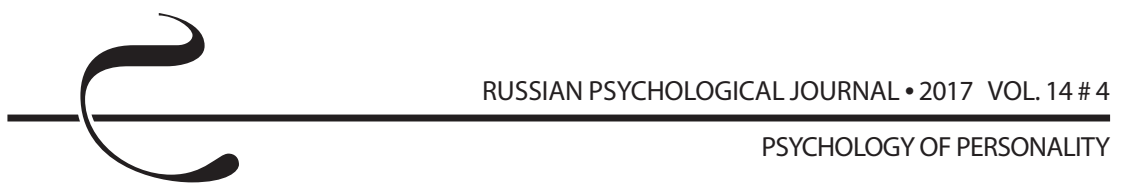

желанием эксплуатировать людей, заставляя их быть орудиями для воплощения антисоциальных замыслов [20].

Определены основные противоречия негативиста, осуществляемые на уровне ценностей: склонность к новым ощущениям не базируется на развитом самоконтроле, нонконформизм не связан с принятием традиционных ценностей, а стремление к доминированию не соответствует персональным достижениям. Отвержение всего позитивного, доброты поддерживает негативное примитивное мироощущение, основанное на эгоцентризме. Неудовлетворенность прошлым, отвержение настоящего и будущего свидетельствуют о непринятии ценностей жизни. Наблюдаются примитивность потребностей и ценностей, безынициативность, низкая оценка своих возможностей и ресурсов, слабая воля. Представители данной типологии, обладая косным и шаблонным мышлением, ригидны, не готовы к инновациям, их картина мира основана на жестких схемах, далеких от толерантности. Базовое ценностно-смысловое противоречие - между потребностью самовозвышения и низким личностным потенциалом. Ценностно-смысловая структура негативиста имеет свою специфику: непринятие жизни, чувство несправедливости, ощущение неудовлетворенности и обделенности сочетаются с иллюзией своей исключительности и стремлением к компенсаторной активности. Через призму сложных, антагонистических личностных противоречий высвечиваются проблемы негативной личностной идентичности и отчужденной активности, создающей преграды на пути к самореализации и поиску собственной подлинной сущности.

У лиц с оппозиционными установками, по сравнению с негативистами, не выражено стремление к власти. Субъекта с оппозиционными установками можно характеризовать как примитивную личность с невыраженными духовными потребностями и стертым стремлением к личностному росту. Главное ценностно-смысловое противоречие наблюдается между потребностью в получении материальных благ и отсутствием желания прилагать усилия. Большой интерес представляет вопрос: каким образом такие субъекты, являющиеся носителями всевозможных деструкций и противоречий, неспособные к самореализации, обладают возможностью пробуждать протестную мотивацию и настраивать на протест других? Вероятно, это достигается посредством манипулятивности, креативности, лживости и хитрости. Отметим, что лица с оппозиционными установками не стремятся к активному отстаиванию идеалов и ценностей; более существенна в структуре личности готовность к обвинению, подстрекательству и использованию других в своих интересах. Неустойчивость субъектной позиции, низкая значимость ценностей в структуре личности, вероятно, могут свидетельствовать о возможности быстрой смены ценностей и идеалов, в зависимости от обстоятельств. 


\section{Заключение}

Результаты исследования позволяют сделать следующие выводы:

1. Как показало исследование, при системном анализе феномена протеста значимым является не только учет макросоциальных детерминант, основных социокультурных факторов исторического процесса, но и исследование микроконтекстов, в сфере которых возникает индивидуальная протестная активность.

2. Протестная активность может рассматриваться как личностная характеристика и анализироваться как разновидность модусов бытия.

3. Протестная активность ярко проявляет уровень экзистенциального развития человека, личностную позицию по отношению к миру.

4. Эмпирически доказано, что именно несоответствие между бытием и долженствованием, желание распространять собственный масштаб, расширять возможности влияния на микро- и макросоциум и несоответствующие, объектные типы позиционирования личности - составляют суть ценностно-смысловых противоречий в деструктивных формах протеста. Эти противоречия весьма рельефно акцентируют сложности, связанные с несформированностью идентичности и отчужденной активностью, затрудняющей реализацию аутентичного бытия. Причем причины этого феномена могут быть объяснены выявленным во всех без исключения деструктивных формах режимом внешней детерминации личностной активности, который не позволяет личности выдерживать неопределенность внутреннего и внешнего мира. Характер такого бытия не позволяет понимать границы своей активности и максимально реализовывать бытийные возможности.

5. Чрезмерная фиксация на препятствиях, субъективно воспринимаемых как фрустрирующие факторы, не позволяет полноценно удовлетворять основные потребности. Невозможность управлять жизнью и отслеживать важные события, слабая мотивация к конструктивному самоосуществлению и творческому самовыражению, отказ от рефлексии экзистенциальных вопросов формируют отрицательное, враждебное отношение к миру. Постоянно накапливаясь и приобретая все новые нюансы, эти противоречия указывают на высокую потенциальную готовность представителей деструктивных форм к протестным действиям в самых разных ситуациях, представляя угрозу самой личности и социуму.

6. Комплекс выделенных и описанных противоречий протестной активности в преломлении к конкретным и типичным жизненным реалиям заостряет проблему отсутствия интереса к конструктивному сотрудничеству. Для предупреждения нарастаний деструктивной протестной активности личности важно обратить особое внимание на динамику и содержание социализации, в процессе которой происходит формирование ценностей 


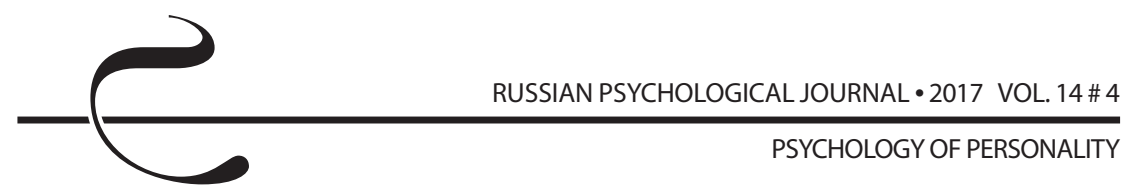

и личностных качеств субъекта: ответственности, самостоятельности, включенности в социальную жизнь. Субъектному позиционированию личности способствует ощущение востребованности, а также появление возможности реально влиять на социальные процессы.

Таким образом, в контексте субъектно-бытийного подхода протестная активность личности предстает как системный и процессуальный феномен и понимается не как неудовлетворенность и дезадаптация, а как формирование способности личности действовать в динамично изменяющихся условиях, разрешая противоречия современности. В зависимости от того, каким образом личность преодолевает внутренние и внешние разноуровневые противоречия, содержательно изменяются специфичные составляющие протестных форм, проясняя позицию личности по отношению к бытию.

\section{Литература}

1. Абакумова И. В., Рядинская Е. Н., Голубова В. М. Системно-структурный анализ теорий психологических трансформаций личности // Российский психологический журнал. - 2017. - Т. 14, № 1. - С. 10-24.

2. Леонтьев Д. А. Личностный потенциал: структура и диагностика. - М. : Смысл, 2011. -680 с.

3. Магомед-Эминов М. Ш. Позитивная психология человека. От психологии субъекта к психологии бытия : в 2-х т. - М. : Психоаналитическая Ассоциация Российской Федерации, 2007. - Т. 1. - 560 с.

4. Знаков В. В. XXI век: Изменения в мире человека и новый этап развития психологии субъекта // Личность и бытие: человек как субъект социокультурной реальности : материалы Всероссийской научно-практической конференции / под ред. З. И. Рябикиной и В. В. Знакова. - Краснодар: Изд-во КубГУ, 2016. - С. 5-14.

5. Тульчинский Г.Л. Сдвиг гуманитарной парадигмы, трансцендентальный субъект и постчеловеческая персонология // Методология и история психологии. - 2010. - Т. 5, Вып. 1. - С. 32-51.

6. Рубинштейн С. Л. Бытие и сознание. Человек и мир. - М. : Питер, 2003. $512 \mathrm{c}$.

7. Фоменко Г.Ю. Модусы бытия личности в контексте субъектно-бытийного подхода // Психология субъекта и психология человеческого бытия / под ред. В. В. Знакова, З. И. Рябикиной, Е. А. Сергиенко. - Краснодар : Изд-во КубГУ, 2010. - С. 158-174.

8. Шиповская В. В. Взаимосвязь беспомощности и личностных свойств в старшем подростковом возрасте // Российский психологический журнал. - 2008. - Т. 5, № 2. - С. 76-78. 
9. Гусейнов А. Ш., Фоменко Г. Ю., Рябикина 3. И. Протестная активность личности в контексте субъектно-бытийного подхода // Человек. Сообщество. Управление. - 2015. - № 3 (16). - С. 6-21.

10. Фоменко Г. Ю. Самоопределение личности: актуальные направления исследовательского поиска в контексте субъектно-бытийного подхода // Личностная идентичность: вызовы современности : материалы Всероссийской психологической научно-практической конференции (с иностранным участием) / под ред. 3. И. Рябикиной и В. В. Знакова. - Краснодар : Изд-во КубгУ ; Майкоп : Изд-во Адыгейского гос. ун-та ; М. : Изд-во ИП РАН, 2014. - С. 37-39.

11. Шиповская В. В. Модусы преодолевающей активности личности в контексте субъектно-бытийного подхода // Известия Сочинского государственного университета. - 2013. - № 4-2 (28). - С. 89-93.

12. Брушлинский А. В. Психология субъекта. - М. ; СПб. : Алетейя, 2003. - 272 с.

13. Рябикина 3. И. Субъектно-бытийный подход к изучению развивающих личность противоречий // Психологический журнал. - 2008. - Т. 29, № 2. - С. 78-87.

14. Рябикина 3.И., Танасов Г.Г. Субъектно-бытийный подход кличности и анализу ее со-бытия с другими (конструктивная версия постмодернистских «настроений») // Человек. Сообщество. Управление. - 2010. - № 2. - С. 4-19.

15. Рябикина 3. И. Особенности современности: изменчивая реальность и гибкая личностная идентичность // Личность и бытие: человек как субъект социокультурной реальности : материалы Всероссийской научно-практической конференции / под ред. 3. И. Рябикиной и В. В. Знакова. - Краснодар : Изд-во КубГУ, 2016. - С. 15-20.

16. Знаков В. В., Рябикина 3. И. Психология человеческого бытия. - М. : Смысл, 2017. - 416 с.

17. Фоменко Г. Ю. Современная социокультурная реальность и психология безопасности личности в контексте субъектно-бытийного подхода // Личность и бытие: человек как субъект социокультурной реальности : материалы Всероссийской научно-практической конференции / под ред. 3. И. Рябикиной и В. В. Знакова. - Краснодар: Изд-во КубГУ, 2016. - С. 21-29.

18. Гусейнов А. Ш. Протест как фактор деструктивного поведения подростков и молодежи // Вестник Санкт-Петербургского университета. Психология. Социология. Педагогика. Серия 12. - 2011. - Вып. 2. - С. 116-121.

19. Гусейнов А. Ш. Негативный потенциал протеста: психологический анализ // Армия и общество. - 2013. - № 1. - С. 169-175.

20. Гусейнов А. Ш. Психологический анализ систем противоречий, характерных для субъекта, включенного в спортивную деятельность // Физическая культура, спорт - наука и практика. - 2015. - № 1. - С. 43-51. 


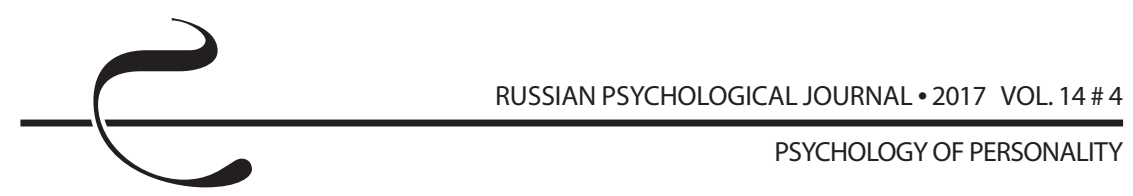

21. McDermott M. R., Barik N. B. Developmental Antecedents of Proactive and Reactive // Journal of Motivation, Emotion, and Personality. - 2014. - Vol. 2, Issue 1. - P. 22-31.

22. Баранова Г. В. Методика анализа протестной активности населения России // Социологические исследования. - 2012. - № 10. - С. 143-152.

23. Blader S. L. What leads organizational members to collectivize? Injustice and identification as precursors of union certification // Organization Science. - 2007. - Vol. 18. - P. 108-126.

24. Gurr T. R. Peoples versus States: Minorities at risk in the new century. - Washington, DC : US Institute of Peace Press, 2000.

25. Klandermans B., Van der Toorn J., Van Stekelenburg J. Embeddedness and identity: How immigrants turn grievances action // American Sociological Review. - 2008. - Vol. 73. - P. 992-1012.

26. Van Stekelenburg J., Klandnermans B. The social psychology of protest // Current Sociology. - 2013. - Vol. 61 - P. 886-905.

27. Van Zomeren M., Leach C. W., Spears R. Protesters as'passionate economists': A dynamic dual pathway model of approach coping with collective disadvantage // Personality and Social Psychology Review. - 2012. - Vol. 16, Issue 2. - P. 180-199.

28. Folger $R$. Rethinking equity theory: A referent cognitions model // Justice in Social Relations / H. W. Bierhoff, R. L. Cohen, J. Greenberg (eds.). - N. Y. : Plenum, 1986. - P. 145-162.

29. Foster M. D., Matheson K. Perceiving and responding to the personal group discrimination discrepancy // Personality and Social Psychology Bulletin. 1999. - Vol. 25, № 10. - P. 1319-1329.

30. McCarthy J.D., Zald M. N. Resource mobilization and social movements: A partial theory // American Journal of Sociology. - 1977. - Vol. 82. - P. 1212-1241.

31. Drury J., Reicher S. Collective psychological empowerment as a model of social change: Researching crowds and power // Journal of Social Issues. 2009. - Vol. 65, № 4. - P. 707-725.

32. Hogg M. A., Graham M. V. Social psychology. - London : Person Education Limited, 2011. - 6th ed. - $763 \mathrm{p}$.

33. Gurr T. R. «Why Men Rebel Redux: How Valid Are Its Arguments 40 Years On?» E-International Relations. - URL: http://www.e-ir.info/2011/11/17/ (дата обращения: 02.06.2017).

\section{References}

1. Abakumova I. V., Ryadinskaya E. N., Golubova V. M. System and structural analysis of theories of psychological transformation of personality. Rossiiskii psikhologicheskii zhurnal - Russian Psychological Journal, 2017, V. 14, no. 1, pp. 10-24 (in Russian). 
2. Leont'ev D. A. Lichnostnyi potentsial: struktura idiagnostika [Personal potential: structure and diagnostics]. Moscow, Smysl Publ., 2011.680 p.

3. Magomed-Eminov M.Sh. Pozitivnaya psikhologiya cheloveka. Ot psikhologii sub"ekta k psikhologii bytiya: v 2-kh t. [Positive psychology of the person. From the psychology of subject to the psychology of being: in 2 volumes]. Moscow, Russian Psychoanalytic Association Publ., 2007, V. 1. 560 p.

4. Znakov V. V. XXI vek: Izmeneniya v mire cheloveka i novyi etap razvitiya psikhologii sub"ekta [21st century: changes in a man's world and a new stage in the psychology of the subject]. Materialy Vserossiiskoi nauchno-prakticheskoi konferentsii "Lichnost' i bytie: chelovek kak sub"ekt sotsiokul'turnoi real'nosti" [Proc. the All-Russian Theoretical and Practical Conference "Personality and being: A man as the subject of sociocultural reality"]. Krasnodar, Kuban State University Publ., 2016, pp. 5-14.

5. Tul'chinskii G. L. A shift in the humanitarian paradigm, the transcendental subject and post-human personology. Metodologiya i istoriya psikhologii Methodology and History of Psychology, 2010, V. 5, no. 1, pp. 32-51 (in Russian).

6. Rubinshtein S. L. Bytie i soznanie. Chelovek i mir [Being and consciousness. A man and the world]. Moscow, Piter Publ., 2003. 512 p.

7. Fomenko G. Yu. Personal modes of being in the context of the subjectiveexistential approach. In: Znakov V. V., Ryabikina Z. I., Sergienko E. A. Psikhologiya sub"ekta i psikhologiya chelovecheskogo bytiya [The subject's psychology and the psychology of human being]. Krasnodar, Kuban State University Publ., 2010, pp. 158-174.

8. Shipovskaya V.V. Relationship among helplessness and personal characteristics in adolescents in a senior high school. Rossiiskii psikhologicheskii zhurnal Russian Psychological Journal, 2008, V. 5, no. 2, pp. 76-78 (in Russian).

9. Guseinov A. Sh., Fomenko G. Yu., Ryabikina Z. I. Protest activity in the context of the subjective-existential approach. Chelovek. Soobshchestvo. Upravlenie Human. Community. Management, 2015, no. 3 (16), pp. 6-21 (in Russian).

10. Fomenko G. Yu. Samoopredelenie lichnosti: aktual'nye napravleniya issledovatel'skogo poiska v kontekste sub"ektno-bytiinogo podkhoda [Selfidentity: Current trends in research in the context of the subjective-existential approach]. Materialy Vserossiiskoi psikhologicheskoi nauchno-prakticheskoi konferentsii (s inostrannym uchastiem) "Lichnostnaya identichnost': vyzovy sovremennosti" [Proc. the All-Russian Psychological Theoretical and Practical Conference (with foreign participation) "Personal identity: modern challenges"]. Krasnodar, Kuban State University Publ., 2014, pp. 37-39.

11. Shypovskaya V.V. Modes of the person's overcoming activity in the context of the subjective-existential approach. Izvestiya Sochinskogo gosudarstvennogo 
universiteta - Izvestiya Sochi State University, 2013, no. 4-2 (28), pp. 89-93 (in Russian).

12. Brushlinskii A. V. Psikhologiya sub"ekta [The subject's psychology]. Moscow, Aleteiya Publ., 2003. 272 p.

13. Ryabikina Z. I. The subjective-existential approach to studying conflicts developing personality. Psikhologicheskii zhurnal, 2008, V. 29, no. 2, pp. 78-87 (in Russian).

14. Ryabikina Z. I., Tanasov G. G. The subjective-existential approach to the person and the analysis of his/her co-existence with others (a constructive version of post-modern sentiments). Chelovek. Soobshchestvo. Upravlenie - Human. Community. Management, 2010, no. 2, pp. 4-19 (in Russian).

15. Ryabikina Z. I. Osobennosti sovremennosti: izmenchivaya real'nost' i gibkaya lichnostnaya identichnost' [Features of modernity: The changing reality and a flexible personal identity]. Materialy Vserossiiskoi nauchnoprakticheskoi konferentsii "Lichnost' i bytie: chelovek kak sub"ekt sotsiokul'turnoi real'nosti" [Proc. the All-Russian Theoretical and Practical Conference "Personality and being: A man as the subject of sociocultural reality"]. Krasnodar, Kuban State University Publ., 2016, pp. 15-20.

16. Znakov V.V., Ryabikina Z. I. Psikhologiya chelovecheskogo bytiya [Psychology of human existence]. Moscow, Smysl Publ., 2017. 416 p.

17. Fomenko G. Yu. Sovremennaya sotsiokul'turnaya real'nost' i psikhologiya bezopasnosti lichnosti v kontekste sub"ektno-bytiinogo podkhoda [Modern socio-cultural reality and the psychology of human security in the context of the subjective-existential approach]. Materialy Vserossiiskoi nauchno-prakticheskoi konferentsii "Lichnost' i bytie: chelovek kak sub"ekt sotsiokul'turnoi real'nosti" [Proc. the All-Russian Theoretical and Practical Conference "Personality and being: A man as the subject of sociocultural reality"]. Krasnodar, Kuban State University Publ., 2016, pp. 21-29.

18. Guseinov A. Sh. Protest as a factor in the destructive behavior among adolescents and young people. Vestnik Sankt-Peterburgskogo universiteta. Psikhologiya. Sotsiologiya. Pedagogika - Vestnik of Saint Petersburg University. Series 12. Psychology. Sociology. Pedagogy, 2011, V. 2, pp. 116-121 (in Russian).

19. Guseinov A. Sh. The negative potential of protest: A psychological analysis. Armiya i obshchestvo - Army and Society, 2013, no. 1, pp. 169-175 (in Russian).

20. Guseinov A. Sh. The psychological analysis of contradiction systems in subjects engaged in sports activities. Fizicheskaya kul'tura, sport-nauka ipraktika-Physical Education, Sports - Science and Practice, 2015, no. 1, pp. 43-51 (in Russian).

21. McDermott M. R., Barik N. B. Developmental antecedents of proactive and reactive. Journal of Motivation, Emotion, and Personality, 2014, V. 2, Issue 1, pp. 22-31. 
22. Baranova G. V. A technique for analyzing protest activity in Russians. Sotsiologicheskie issledovaniya - Sociological Studies, 2012, no. 10, pp. 143-152 (in Russian).

23. Blader S. L. What leads organizational members to collectivize? Injustice and identification as precursors of union certification. Organization Science, 2007, V. 18, pp. 108-126.

24. Gurr T. R. Peoples versus States: Minorities at risk in the new century. Washington, DC, US Institute of Peace Press, 2000.

25. Klandermans B., Van der Toorn J., Van Stekelenburg J. Embeddedness and identity: How immigrants turn grievances action. American Sociological Review, 2008, V. 73, pp. 992-1012.

26. Van Stekelenburg J., Klandnermans B. The social psychology of protest. Current Sociology, 2013, V. 61, pp. 886-905.

27. Van Zomeren M., Leach C. W., Spears R. Protesters as'passionate economists': A dynamic dual pathway model of approach coping with collective disadvantage. Personality and Social Psychology Review, 2012, V. 16, Issue 2, pp. 180-199.

28. Folger R. Rethinking equity theory: A referent cognitions model. In: H. W. Bierhoff, R. L. Cohen, J. Greenberg (eds.) Justice in Social Relations. N. Y., Plenum, 1986, pp. 145-162.

29. Foster M. D., Matheson K. Perceiving and responding to the personal group discrimination discrepancy. Personality and Social Psychology Bulletin, 1999, V. 25, no. 10, pp. 1319-1329.

30. McCarthy J. D., Zald M. N. Resource mobilization and social movements: A partial theory. American Journal of Sociology, 1977, V. 82, pp. 1212-1241.

31. Drury J., Reicher S. Collective psychological empowerment as a model of social change: Researching crowds and power. Journal of Social Issues, 2009, V. 65, no. 4, pp. 707-725.

32. Hogg M. A., Graham M. V. Social psychology. London, Person Education Limited, 2011, 6th ed. 763 p.

33. Gurr T. R. "Why Men Rebel Redux: How Valid Are Its Arguments 40 Years On?" [Online] E-International Relations. Available at: http://www.e-ir.info/2011/11/17/ (Accessed 02 June 2017). 